\title{
Perspektif Pengajaran Teori Intelligent Design di Sekolah Menengah Atas
}

\author{
Asriah Nurdini Mardiyyaningsih \\ Pendidikan Biologi, FKIP Universitas Tanjungpura
}

\begin{abstract}
Abstrak
Teori Intelligent Design (ID) merupakan teori tantangan terhadap teori evolusi yang diperkenalkan pada tingkat sekolah menengah. Tulisan ini mengkritisi mengenai perlunya perspektif pengajaran teori ID yang tepat sehingga mencegah pemberian pesan pembelajaran sains yang keliru, pada tiga ranah yaitu perbedaan fundamental antara teori ID dan evolusi, adanya proporsi pengajaran teori ID yang mendominasi arah penjelasan evolusi dan adanya intervensi agama dalam mendukung pembuktian sains dalam evolusi. Tulisan ini juga mengajukan pola pembelajaran yang menekankan pada kemampuan berpikir kritis dan debat sebagai solusi cara pengajaran teori ID di SMA. Pada akhirnya, dapat disimpulkan bahwa teori ID dapat diajarkan di sekolah dengan membatasi pada paparan saintifik terkait bukti-bukti ilmiah dan menghindari bukti teologis serta dengan mengedepankan kemampuan berpikir kritis dalam menganalisis buktibukti saintifik dalam kaitan menerima teori ID atau sebaliknya mempertahankan teori evolusi.
\end{abstract}

Keyword: Intelligent Design, teori evolusi, perbedaan fundamental, proporsi pengajaran, agama, berpikir kritis

\section{Pendahuluan}

Evolusi merupakan salah satu materi inti dalam pembelajaran biologi. Subjek ini juga menempati posisi sentra dalam perkembangan ilmu biologi. Banyak ahli biologi mengklaim bahwa evolusi menjadi kunci pemahaman menyeluruh terhadap seluruh bentuk kehidupan yang ada di bumi melalui penjelasan logik yang menghubungkan antar berbagai organisme yang ada di bumi dan keterkaitannya dengan lingkungan bumi (Cherif et al., 2001). Evolusi juga menjadi kunci dalam memahami keseluruhan ilmu biologi yang tadinya dipelajari terpisah dalam beberapa disiplin ilmu, seperti anatomi, fisiologi, dan genetika, dll (Alles, 2001).

Namun tidak dapat dipungkiri bahwa kebenaran teori evolusi sendiri masih terus mendapat tantangan hingga saat ini dikarenakan pemahaman evolusi tidak dapat dibuktikan melalui eksperimen, melainkan melalui penafsiran terhadap berbagai bukti evolusi yang ditemukan. Hal ini membuka ruang bagi perkembangan teori lain di masyarakat untuk menyanggah teori evolusi. Teori Intelligent Design (ID) atau di Indonesia lebih dikenal sebagai teori Perancangan Cerdas (PC) merupakan 
salah satu teori yang masuk dalam kategori ini.

Masuknya pembelajaran teori ID dalam pembelajaran evolusi SMA didukung oleh silabus KTSP Biologi SMA Kelas XII pada Standar Kompetensi 4 (Memahami teori evolusi serta implikasinya pada salingtemas), terutama pada kompetensi dasar 4.3 (menjelaskan kecenderungan baru tentang teori evolusi) (Lampiran Standar Isi Sekolah Menengah, 2006 dalam Tarihoran, 2012). Banyak guru Biologi yang mengartikan kecenderungan baru teori evolusi adalah mengarah pada pembahasan tentang teori ID. Kecenderungan ini juga tampak dari penelusuran isi buku elektronik (BSE) pada bagian kecenderungan baru teori evolusi. BSE karangan Herlina, dkk (2009), Subardi dkk (2009) dan Kistinnah (2009), keseluruhannya diterbitkan oleh Pusat Perbukuan Depdiknas, Jakarta menyajikan pembahasan mengenai teori ID.

Kecenderungan baru yang
didapat berupa keleluasaan
kurikulum untuk mengajarkan teori kontra evolusi di sekolah di satu sisi merupakan upaya untuk menyajikan pembelajaran secara aktual dan kontekstual seperti yang terjadi di masyarakat. Namun demikian, cara pembelajaran teori ID di SMA juga harus disikapi secara hati-hati oleh guru SMA agar tidak memberikan arah pembelajaran sains yang negatif. Tulisan ini akan mengkritisi penekanan pembelajaran pada perbedaan fundamental teori ID dan evolusi, proporsi pengajaran argumentasi teori ID dan evolusi yang tepat, serta adanya penggunaan bukti teologis dalam membelajarkan teori ID. Pada akhirnya tulisan ini mengajukan solusi pengajaran teori ID secara saintifik

ISI

\section{Perlunya Pembelajaran Mengenai Perbedaan Fundamental Antara Teori ID dengan Teori Evolusi}

Dalam mengajarkan teori ID, banyak guru yang menyandarkan perbedaan pandangan teori ID dengan evolusi adalah pada penjelasan mengenai asal-usul manusia. Meskipun "menerima" bahwa manusia memiliki kekerabatan yang dekat dan bahkan berasal dari satu nenek moyang dengan kera merupakan implikasi dari teori evolusi, namun sebenarnya tantangan teori ID terletak pada penjelasan yang lebih fundamental, yakni dasar pemikiran naturalis.

Teori Inteligent Design berpegang pada keyakinan bahwa makhluk hidup kompleks di bumi tercipta karena adanya intervensi secara utuh dari kekuatan yang berasal dari luar kekuatan alam (supranatural atau dalam hal ini disebut sebagai designer), bukan karena peristiwa random di alam (Heady, 2003). Teori ini banyak dituding sebagai neo-creationist karena keberadaan unsur supranaturalnya (Wikipedia, 2009), namun sebenarnya banyak ilmuwan di bidang sains murni yang menjadi pendukung teori ini serta memberikan kontribusi untuk membuktikan eksistensi teori ini.

Dalam pembelajaran biologi SMA, tokoh pendukung ID yang populer dan banyak dibahas kemungkinan besar adalah Harun Yahya. Tokoh ini populer karena menerbitkan buku berjudul "Bagaimana Sains Modern Membantah Darwinisme" yang 
secara konsisten mempertanyakan teori evolusi. Selain Yahya, sebenarnya masih terdapat sederetan ilmuwan lain yang mendukung teori ID, seperti Jonathan Wells, Michael J. Behe (bidang biologi), David Menton (bidang anatomi), Dean Kenyon, Michael Denton dan Charlers Taxton (bidang biokimia), Donald Chittick (bidang kimia), serta Carl Friedrich von Weizsacker, Robert Matthews dan Jocelyn Bell Burnll (bidang fisika). Selain itu, terdapat pula matematikawan William Dembski dan Owen Gingerich (astronomi dan sejarah ilmu pengetahuan) yang juga mendukung paham ID ini (Mahladi, 2006).

Dalam menerangkan bantahannya terhadap teori evolusi, banyak diantara ilmuwan tersebut yang mempertanyakan mekanisme evolusi yang dijelaskan oleh evolusi Darwin, yaitu seleksi alam dan mekanisme evolusi yang dijelaskan oleh evolusi neo-Darwinian, yakni mutasi. Seleksi alam sendiri telah menjadi kesepakatan umum, hanya dapat bekerja apabila terdapat sumber variasi baru di antara individu atau populasi. Ketersediaan sumber variasi baru berdasarkan sains modern, disediakan oleh mutasi. Dengan demikian, banyak diantara tantangan yang dialamatkan pada teori evolusi adalah membuktikan bahwa mutasi dapat terjadi dan fungsional untuk terjadinya evolusi makro (ditandai dengan adanya perubahan spesies).

Yahya (2005), misalnya mempertanyakan mekanisme mutasi acak dalam peranannya sebagai mekanisme alternatif dalam pewarisan evolusioner. Hal ini terutama dikarenakan hingga ia menulis bukunya, tidak terdapat bukti kemunculan makhluk hidup baru berdasarkan mutasi. Dari ribuan eksperimen yang dilakukan, tidak tampak arah menguntungkan mutasi, bahkan sebaliknya, justru merugikan. Keraguan utamanya terhadap teori evolusi adalah tidak ditemukannya makhluk hidup dengan "bentukbentuk transisi" yang diasumsikan oleh teori evolusi (neo-Darwinian). Darwin sendiri, dalam bukunya The Origin of Species, memprasyaratkan adanya fosil transisi dalam jumlah berlimpah sebagai syarat sahnya teori evolusi yang dikemukakannya.

Yahya (2005) juga mempertanyakan evolusi melalui pengajuan beberapa teori tandingan untuk membuktikan bahwa kehidupan terlalu kompleks untuk dijelaskan melalui terminologi kejadian acak (random) di alam. Michael Behe mencetuskan "irreducible complexity" dalam menjelaskan bahwa alam merupakan sistem tunggal dengan bagian-bagian yang saling terintegrasi. Penghilangan bagian tertentu akan menyebabkan kerusakan fungsi sistem keseluruhan. Hal ini dianalogikan juga terjadi dalam makhluk hidup sehingga kemungkinan terjadinya mutasi, sebagai mekanisme evolusi, yang akan menghilangkan bagian tertentu justru tidak mungkin terjadi. Terlebih lagi, evolusi tidak perlu terjadi, mengingat semua makhluk hidup, bahkan makhluk paling primitif sekalipun, memiliki desain anatomi dan fisiologis yang tidak bercacat dan memiliki kemampuan adaptasi yang sempurna di lingkungannya. Argumentasi lainnya datang dari William Dembski melalui teori specified complexity yang menyatakan bahwa protein fungsional dalam tubuh yang 
terbentuk dikendalikan oleh susunan DNA, yang dapat dianalogikan sebagai kata yang terbentuk dari huruf. Sebagaimana ketidakmungkinan membentuk kata yang fungsional dengan susunan huruf random, maka tidak mungkin pula membuat protein fungsional dari susunan random DNA akibat peristiwa mutasi evolusioner di alam. Argumen paling tenar adalah dari Michael Denton, penulis buku Evolution: A Theory in Crisis di tahun 1987 mengungkapkan teori "molecular equidistance" berisi argumen dari observasinya terhadap kesamaan protein sitokrom $\mathrm{C}$ dari sampel ikan yang diperkirakan sebagai nenek moyang dengan turunannya berturut-turut yaitu amfibi, reptil, burung dan mamalia (Wikipedia, 2009, Mahladi, 2006).

Selain ketiga argumen di atas, banyak pula argumen pendukung teori ID lainnya. Sprachen (2007) mengungkapkan pendukung teori ID menggunakan penjelasan Jay Gould dan Niles Eldredge mengenai model punctuated equilibrium, yakni bahwa berdasarkan kajian fosil, kemunculan makhluk hidup baru tidaklah terjadi secara bertahap dan kumulatif, melainkan secara tiba-tiba. Dengan demikian, penjelasan evolusi mengenai terbentuknya makhluk hidup baru menjadi bertentangan dengan fakta baru yang dikemukakan. Selain itu, dalam Wikipedia $^{2}$ (2008) terungkap bahwa fakta lain yang digunakan untuk menentang teori evolusi adalah pemikiran berdasarkan logika fisika, hukum Termodinamika II juga menyatakan bahwa dengan berlalunya waktu, entropi (limbah energi) yang dihasilkan justru akan bertambah banyak, sehingga menyatakan dengan berlalunya waktu, spesies akan berubah menuju arah yang sempurna adalah hal yang menyalahi hukum alam itu sendiri.

Dari pembahasan di atas tampak bahwa dalam membelajarkan teori ID, guru tidak hanya cukup mengaitkan semata ketidaksetujuan tentang asal-usul manusia, namun harus lebih menyajikan pembelajaran yang fundamental, yang menekankan pada adanya penggalian fakta untuk menerima atau menentang tentang terjadinya proses randomisasi di alam. Hal ini perlu untuk diketahui oleh siswa untuk memahami bagaimana penerimaan terhadap suatu teori sains berpengaruh pada seluruh tatanan pemahaman tentang sains itu sendiri. Misalnya implikasi penerimaan teori ID sendiri berarti menghilangkan pemahaman adanya hubungan kekerabatan dalam taksa yang selama ini telah disusun, karena adanya kekerabatan dianalogikan sebagai adanya kedekatan hubungan "saudara" seperti halnya garis keturunan keluarga yang memiliki kemiripan diantara variasinya dan hanya dapat terjadi dengan pemahaman bahwa semua makhluk hidup yang ada di bumi berasal dari satu garis keturunan tunggal. Siswa tidak lagi cukup hanya disuguhkan untuk memilih hanya antara apakah mereka percaya apakah garis ras manusia berasal dari kera atau tidak, namun lebih lanjut mereka harus didorong untuk memikirkan dampak dari teori ini secara keseluruhan. Secara sederhana, siswa umumnya cenderung dapat mengikuti logika evolusi hingga tiba pada pembahasan mengenai garis keturunan manusia. Padahal mereka mengakui adanya kekerabatan yang dekat antara kera dan manusia, seperti misalnya penggunaan kera dalam uji klinis obat dan kosmetik dilakukan karena 
kedekatan kekerabatan kera dan manusia yang ditampilkan dari kedekatan karakter fisiologis mereka.

Dalam mengajukan argumen untuk menantang teori evolusi, ilmuwan pendukung teori ID juga banyak menggunakan bukti yang bersifat molekuler, seperti pembahasan kesamaan biokimiawi sitokrom C, DNA dan protein fungsional, serta garis keturunan. Guru biologi tidak dapat mengharapkan siswa memahami bukti-bukti pertentangan itu tanpa memberikan pemahaman mendasar mengenai mikroevolusi (evolusi pada tingkat molekuler). Pembahasan mengenai evolusi Darwin yang menekankan pada analisis evolusi makro seperti bukti analogi berupa fosil, analogi dan homologi organ, tidak lagi cukup untuk mengantarkan siswa memahami dasar pertentangan teori ID dan evolusi yang sebagian besar pembuktiannya adalah secara molekuler. Oleh karena itu, sebelum sampai pada pembelajaran teori ID, guru terlebih dahulu harus memberikan dasar pemikiran genetika molekuler, terutama berkaitan dengan keterkaitan DNA dan protein fungsional serta mutasi dengan kuat. Pembelajaran genetika sebelum sampai pada pembahasan evolusi menjadi suatu keharusan dan sekuensial, bukan hanya sebagai materi yang terpisah.

\section{Proporsi Penjelasan Teori ID dan Teori Evolusi yang Tepat}

Posisi pembelajaran teori ID yang diberikan setelah membahas mengenai evolusi dan bertindak sebagai teori tantangan, dapat memberikan pesan pembelajaran bahwa teori ID lebih "baik" dalam memberikan tafsiran terhadap keanekaragaman biologis daripada teori evolusi. Hal ini terutama terjadi apabila tidak ada argumentasi bantahan dari pendukung teori evolusi yang disajikan sebagai tantangan terhadap teori ID. Dengan demikian, penyajian argumentasi dari kedua teori perlu diberikan secara proporsional.

Banyak penjelasan yang telah diberikan oleh ilmuwan dalam menantang pemikiran pencetus teori ID. Salah satunya adalah Mark I. Vuletic. Vuletic (1997) memberikan penjelasan yang bertentangan dengan pemahaman pendukung teori ID. Misalnya, penjelasan mengenai analogi DNA dan protein sebagai huruf dan kata yang terbentuk. Analogi DNA sebagai huruf dalam pembentukan kata sebenarnya tidaklah tepat. DNA, bahkan dalam susunannya yang berbeda dan kurang fungsional, masih dapat memberi makna dalam susunan protein, sehingga menjaga organisme tetap hidup meskipun tidak dalam bentuk terbaiknya. Pada akhirnya, perubahan bentuk secara besarbesaran dapat terjadi akibat alterasi gen. Seleksi buatan dan pembudidayaan (breeding) merupakan contoh kasus ini.

Lebih lanjut, Philip T. Spieth (1987) juga menunjukkan bahwa argumen yang diberikan oleh Denton mengandung kesalahpahaman mendasar mengenai evolusi. Michael Denton mengajukan teori "molecular equidistance" yang menunjukkan bahwa antara spesies bakteri (yang dianggap sebagai tetua) dan ikan (turunannya) tidak menunjukkan adanya hubungan sitokrom $\mathrm{C}$ yang lebih dekat. Sitokrom C ikan sendiri lebih memiliki kedekatan dengan kura-kura (reptil) dan anjing (golongan mamalia). Kesalahan mendasar yang dibuat Denton adalah 
asumsinya bahwa evolusi menyatakan adanya perubahan ke arah kesempurnaan (dari bakteria menuju pada garis mamalia), padahal hal tersebut tidak pernah dinyatakan oleh evolusi. Evolusi hanya menarik garis keturunan dari beberapa ancestor tunggal yang digambarkan sebagai pohon evolusi, bukan garis hiererkial. Dengan demikian, sebenarnya tidak ada arah pergerakan menuju kesempurnaan seperti yang diasumsikan oleh Denton. Selain itu, kesalahan terbesar Denton adalah membandingkan antara sitokrom $\mathrm{C}$ bakteri modern dengan sitokrom $\mathrm{C}$ kura-kura dan anjing masa kini untuk menelusuri kemungkinan bakteri sebagai tetua (ancestor) keduanya. Kesalahan Denton adalah bakteri modern tidak dapat bertindak sebagai tetua, karena dalam penjelasan pohon evolusi tampak bahwa keduanya bertindak sebagai "sepupu" dalam kehidupan modern. Dengan demikian argumen Denton justru sebenarnya menguatkan adanya hubungan kekerabatan spesies, dan pada akhirnya mendukung tafsiran evolusi mengenai adanya nenek moyang tunggal pada makhluk hidup (National Centre for Science Education, 2012).

Hal lain yang perlu ditekankan pada argumentasi kontra teori ID adalah kenyataan walaupun hingga saat ini belum ditemukan ancestor awal Gibbon (sejenis orang utan), namun fosil proto-orangutan dapat diwakili oleh Sivapithecus dari India and Griphopithecus dari Turkey. Perbandingan simpanse dan DNA manusia menunjukkan bahwa keduanya $98.4 \%$ identik, dan diambil sebagai bukti kuat memiliki ancestor bersama. Saat ini hanya satu spesies manusia yang bertahan hidup, namun berdasarkan rekaman fosil, terdapat Homo erectus, Homo habilis, and Homo neanderthalensis (Wikipedia ${ }^{2}$, 2008). Sekarang ini telah ditemukan bukti fosil yang menyarankan bahwa ancestor hominoid manusia mungkin terpisah dari primata lainnya pada akhir oligocene atau pada awal miocene.

Satu hal yang menjadi dasar bagi pendukung teori evolusi dalam mebantah pandangan ID adalah hingga saat ini belum ada satupun teori ID yang dapat masuk ke dalam publikasi ilmiah. Hal ini menunjukkan bahwa bukti yang diajukan tidak memenuhi standar kaidah metode ilmiah, seperti yang diungkapkan oleh Biological Society of Washington (Wikipedia ${ }^{2}$, 2008).

Dalam membahas teori ID dalam perspektif dan proporsi yang tepat, diperlukan penekanan pembahasan yang lebih dalam mengenai teori evolusi itu sendiri. Teori evolusi yang digunakan sekarang ini tidak hanya terbatas pada teori evolusi yang dicetuskan oleh Darwin, bapak evolusi, namun lebih jauh lagi pengertian evolusi telah bergeser menjadi berbagai pendekatan yang mapan untuk menginterpretasikan

keanekaragaman biologis dan desain organisme di bumi (Stearns dan Hoekstra, 2003). Posisi Darwin, dalam hal ini sama seperti posisi Mendel, sebagai pencetus genetika, yang teorinya mendasari pengembangan ilmu genetika modern yang tidak semata hanya berpegang pada teori genetika klasik Mendelian semata. Penekanan pembelajaran evolusi juga bergeser pada pengenalan adanya nenek moyang bersama makhluk hidup yang menurunkan semua keanekaragaman di bumi. Hal ini dapat terjadi karena adanya proses 
perubahan biologis dan organik pada organisme dimana keturunan menjadi berbeda dari nenek moyangnya (Parker, 1997; Campbell et al., 2004).

Analogi yang tepat dalam menerangkan evolusi adalah adanya sejarah keluarga (pedigree) dalam ilmu genetika. Peta silsilah keluarga dimulai dengan adanya nenek buyut (nenek moyang bersama). Keturunan yang dihasilkan, memiliki karakter yang serupa, namun tidak persis sama. Keturunan ini selanjutnya menghasilkan keturunan berikutnya, yang akan menghasilkan keturunan yang lebih banyak. Perbedaan karakter antar generasi selanjutnya akan bertambah lebar. Dengan perspektif yang sama, evolusi berupaya untuk menafsirkan semua spesies yang ada di bumi, sebagai spesies yang "bersaudara". Dari pemahaman yang demikian, muncullah istilah kekerabatan antar spesies. Bahkan dari tafsiran kekerabatan, lebih lanjut ilmu taksonomi atau sistematika, yang bertugas membuat klasifikasi (taksa) berdasarkan kedekatan kekerabatan. Karakter setiap taksa ini selanjutnya digunakan oleh ahli lain di bidang zoologi, botani maupun mikrobiologi sebagai dasar penelitian mereka. Oleh karena itu, dapat dibayangkan kepentingan evolusi dalam mendasari biologi.

Meskipun menempati posisi sentral dalam ilmu biologi, evolusi sebagai teori juga merupakan bagian dari sains. Sains memiliki karakter harus berlandaskan bukti saintifik dan kebenarannya dapat berubah sesuai dengan perkembangan pengetahuan. Bukti saintifik adalah penjelasan yang dapat dibatasi pada hal yang dapat diobservasi dan eksperimen yang dapat diulang oleh saintis lainnya. National Academy of Science and Creationism (dalam Wikipedia $^{2}$, 2008), menyebutkan bahwa penjelasan yang tidak berdasarkan bukti empirik tidak dapat dianggap sebagai bagian dari sains. Karakter lain dari sains adalah bebas dari nilai atau bersifat netral (Djunaidi, 2005). Artinya nilai moral (baik atau buruk) berkaitan penggunaan evolusi di dalam tatanan sosial tidak menjadi tanggung jawab ilmu evolusi itu sendiri. Oleh karena itu, Randak (2001) menyarankan untuk membahas evolusi hanya dari sudut pandang sains yang bebas nilai, dan bukan efeknya terhadap bidang kehidupan lainnya untuk menghindari pembahasan nilai atau moral keilmuan.

Oleh karena itu, rasanya tidak pula etis bila dalam membelajarkan teori ID, guru memberikan argumentasi untuk menolak teori evolusi berdasarkan pembahasan mengenai "sikap non-ilmiah" atau dampak penerapan teori evolusi yang tidak secara langsung mematahkan teori evolusi itu sendiri. Misalnya dengan menunjuk perilaku tidak jujur Charles Dawson (1912) yang merekayasa rangka manusia Piltdown dengan menggabungkan fragmen tengkorak mirip manusia dan tulang rahang mirip kera untuk menunjukkan adanya fosil transisi kera-manusia untuk mendukung teori evolusi. Fosil ini dikemudian hari diketahui ketidakasliannya saat Oakley melakukan uji Florin pada tengkorak yang telah disimpan selama 40 tahun di The British Museum. Hal lain juga seperti dampak nilai (moral) penerapan teori evolusi pada tindakan tidak manusiawi penangkaran Ota Benga, anggota suku Pigmi (suku di Afrika Tengah dengan tinggi badan rata-rata 
kurang dari $127 \mathrm{~cm}$ ), di Kebun Binatang Bronx New York yang diklaim sebagai model nenek moyang manusia dan ditampilkan bersama simpanse, gorila dan orang utan. Hal ini kemudian berujung pada tindakan bunuh diri Ota Benga (Sprachen, 2007). Meskipun di masyarakat ini dinilai sebagai argumentasi yang melemahkan teori evolusi, namun hal ini tidak lantas meruntuhkan evolusi sebagai suatu teori ilmu pengetahuan.

Dari pembahasan di atas tampak bahwa kehati-hatian guru dalam memberikan proporsi pembelajaran yang tepat, berupa penyediaan argumentasi dari kedua belah pihak dan pemilihan jenis argumentasi ilmiah yang tepat diperlukan untuk penyajian teori ID di sekolah. Terlepas dari teori mana yang dipercayai oleh guru, dengan memberikan pola pengajaran yang demikian, guru dapat menghindari adanya penggiringan opini siswa pada suatu teori yang lebih "baik" dan membebaskan siswa untuk memilih argumentasi mana yang lebih baik antara teori ID atau teori evolusi secara saintifik.

\section{Adanya Pembuktian dan Interpretasi Agama Dalam Pembahasan Teori ID}

Membelajarkan teori ID di sekolah juga harus dilakukan dengan hati-hati. Teori Inteligent Design berpegang pada keyakinan bahwa makhluk hidup kompleks di bumi tercipta karena adanya intervensi secara utuh dari kekuatan yang berasal dari luar kekuatan alam (supranatural atau dalam hal ini disebut sebagai "designer"), bukan karena peristiwa random di alam (Heady, 2003). Kekuatan supranatural yang dibicarakan disini mengacu pada keberadaan "Tuhan". Banyak guru yang lantas terjebak untuk membelajarkan dan mendukung teori ID menggunakan ayat-ayat suci dalam agama masingmasing, serta menggunakannya untuk menjatuhkan teori evolusi. Bila pola pembelajaran ini yang dilaksanakan, maka siswa akan merasa dibenturkan antara memilih agama dan sains, dan pembelajaran mengenai teori ID tidak lagi berada pada ranah diskusi ilmiah.

Hal ini tidak serta merta berarti tidak boleh memasukkan pembelajaran mengenai "tuhan" di dalam pembelajaran biologi berdasarkan Permendiknas No. 22 Tahun 2006 Tentang Standar Isi Sekolah Dasar dan Menengah, karena pada dasarnya tujuan tertinggi pembelajaran biologi adalah membentuk sikap positif siswa terhadap biologi dengan menyadari keteraturan dan keindahan alam serta mengagungkan kebesaran Tuhan YME (Lampiran Standar Isi Sekolah Menengah, 2006 dalam Tarihoran, 2012). Hal yang harus dihindari adalah penggunaan ayat-ayat suci agama sebagai bukti untuk menjatuhkan teori di dalam sains (evolusi) karena adanya derajat kebenaran yang berbeda antara sains dan agama. Kebenaran dalam sains bersifat relatif dan terus mengalami pembaharuan seiring dengan ditemukannya alat pendukung observasi (pengamatan) yang lebih canggih. Teori di dalam sains akan terus diuji kebenarannya dengan menggunakan logika ilmiah sesuai dengan perkembangan ilmu pengetahuan. Hal ini tentu saja berbeda dengan kebenaran dalam agama yang bersifat mutlak (absolut). Dogma agama tidak pernah diragukan dan diuji 
kebenarannya seperti dalam penerapan sains. Mencampuradukkan pembahasan antara agama dalam membahas teori saintifik berisiko untuk menempatkan benturan sains terhadap agama seperti yang pernah terjadi pada pembahasan teori geosentris/heliosentris. Dogma agama cenderung berpihak pada salah satu teori. Akibatnya, ketika terdapat pembuktian sains yang berbeda dengan dogma agama yang diberikan, kepercayaan masyarakat terhadap agama menjadi berkurang, karena masyarakat menilai agama tidak sesuai dengan fakta alamiah (Jasin, 2008).

Karakter teori ID yang memiliki istilah designer seringkali menggiring pada penyajian argumen yang teologis. Istilah ini pula yang menyebabkan ID seringkali digolongkan sebagai new-creationist. Argumen pendukung teori ID bahkan digolongkan oleh US National Academy of Sciences kedalam argumen teologis (agamis) dan nonsaintifik. Lebih jauh, National Science Teacher Association (asosiasi guru sains di Amerika) mengklasifikasikan teori ini sebagai pseudoscience (Wikipedia, 2009). Di negara besar seperti Amerika, perdebatan mengenai teori asal-usul makhluk hidup mana yang harus diajarkan di sekolah menengah juga menjadi isu hangat di antara guru biologi. Namun demikian, yang menjadi kekhawatiran guru di negara tersebut adalah ketakutan para guru untuk mengacaukan tatanan sains dengan mencampuradukkan antara bukti non-ilmiah yang dikemukakan oleh pendukung ID dengan teori evolusi (ilmiah) yang diajarkan di sekolah. Dukungan terhadap pembelajaran non sains di materi sains (biologi) ditakutkan menjadi titik kelemahan yang akan membingungkan siswa mengenai batasan ilmiah dan non ilmiah. Lebih jauh, para ilmuwan keberatan dengan idealisme pendukung teori ID yang menuntut ditinggalkannya paham materialisme, padahal sains yang selama ini dibangun di atas paham materialisme, sehingga penghancuran terhadap paham materialisme akan menggoncangkan tatanan seluruh sains yang telah dibangun, tidak hanya pada ilmu biologi saja, namun juga kimia dan fisika (Heady, 2003; Randak, 2001). Oleh karena itu, masih terdapat perdebatan antara ilmuwan dan guru sains untuk memasukkan teori ID dalam pembelajaran evolusi mereka. Survei yang dilakukan Trani (2004) mengungkapkan bahwa rata-rata guru yang mendukung pengajaran dan pengembangan teori ID di sekolah menengah bukan dikarenakan memiliki kepentingan konflik dengan agamanya, namun justru karena kekurangan pengetahuan mengenai keilmiahan sains, dan juga kekurangan pemahaman mengenai teori evolusi itu sendiri.

Pembahasan dukungan terhadap teori ID dengan mengemukakan bahwa kelompok evolusionis tidak mempercayai keberadaan Tuhan juga tidak etis untuk dilakukan, karena tidak memiliki dasar ilmiah. Banyak diantara ilmuwan pendukung evolusi yang menerima keberadaan Tuhan. Anonim (2008) menyebutkan Dobzhansky, bapak evolusi modern (neo-Darwinisme) malah menyatakan bahwa menolak evolusi justru menghina keberadaan Tuhan. Hal ini berdasarkan fakta bahwa kepunahan spesies memang terjadi. 
Bila hal ini tidak dianalisis dengan sudut pandang evolusi (perubahan berkala), maka cenderung akan terbentuk asumsi bahwa Tuhan membuat spesies secara berkala dan "membantai" beberapa dari mereka secara berkala juga. Mekanisme seleksi alam juga merupakan penjelasan ilmiah mengenai kebesaran Tuhan yang menciptakan makhluk hidup yang parasit atau jauh hidup di bawah permukaan tanah atau dasar laut. Karena tanpa penjelasan evolusi, akan muncul pertanyaan mengapa Tuhan menciptakan sebagian makhluk hidup sedemikian padahal Tuhan dapat menciptakan makhluk hidup sempurna seluruhnya.

Dengan demikian, pengajaran teori ID dengan memasukkan logika bahwa agama mendukung adanya teori penciptaan creationist, tidaklah tepat. Segala sesuatu yang berbasiskan pada agama dan kepercayaan (religion) sifatnya tidak terbantahkan, dan karenanya tidak sesuai dengan karakteristik sains, yang selalu berkembang dan dapat mengalami perubahan. Lebih jauh, tidak semua pendukung teori evolusi adalah atheis, dan tidak pula semua pendukung teori ID adalah orang beragama. Bahkan saat ini timbul pula aliran ketiga, yakni creationist yang mempercayai Tuhan menciptakan makhluk hidup melalui tahapan dalam evolusi biologi (Mahladi, 2006). Untuk menghindari adanya bias dalam mengajarkan teori ID sebagai kontra evolusi diperlukan perspektif pengajaran yang tepat, yakni perspektif sains.

\section{Mengedepankan Proses dan Sikap Ilmiah Dalam Membelajarkan Teori ID}

Salah satu cara yang efektif bagi guru dalam mengajarkan kedua teori ini secara berimbang adalah dengan menjadi fasilitator dalam menyediakan fakta saintifik antara teori evolusi dan teori ID. Pandangan yang bebas opini akan membantu siswa untuk berorientasi dalam perdebatan ilmiah. Sesuai dengan pengajaran sains sebagai suatu sikap dan proses, guru dapat menekankan mengenai batasan sains sebagai sesuatu yang dapat diindera (diobservasi). Agar didapatkan pemahaman yang lebih mendalam, maka akan sangat membantu apabila pengajaran juga didukung dengan melakukan perdebatan antara dua sisi teori. Perdebatan akan membantu siswa dalam mengembangkan kemampuan berargumentasi dan pada akhirnya mendorong kemampuan berpikir kritis.

Berpikir kritis dapat diartikan sebagai kemampuan untuk memikirkan apakah sesuatu masuk akal atau tidak (reasonable) (Ennis dalam Lutfi, 2003), atau sebagai cara berpikir untuk mendapatkan pengetahuan yang relevan dan reliabel (Schafersman, 1991). Karakter seorang siswa yang berpikir kritis adalah memiliki alasan dalam memutuskan sesuatu dapat dipercayai atau tidak. Proulx (2004) menyatakan bahwa siswa yang berpikir kritis akan mengambil langkah yang hati-hati dalam melakukan analisis, pengujian dan mengevaluasi argumen, sehingga dapat beralasan dengan logis dan dapat sampai pada kesimpulan yang dapat dipercaya (Proulx, 2004; Schafersman, 1991). Sebagai konsekuensinya, siswa tersebut akan memiliki pandangan yang terbuka terhadap suatu permasalahan, dan bukannya dangkal dan semata 
melibatkan emosi (Moore, 2005; Proulx, 2004).

Dalam mendukung siswa untuk berpikir kritis, guru dapat membantu dengan memberikan contoh pertimbangan fakta secara logik dalam memilih salah satu teori yang dipercayai. Misalnya dalam membahas pengaruh penangkaran Ota Bengami dalam keruntuhan teori evolusi, adalah sesuatu yang tidak beralasan, karena hal tersebut meski berkaitan namun tidak bersifat mementahkan teori evolusi secara langsung, melainkan menyoroti sifat moral materialisme. Dengan demikian, argumen ini meskipun penting tidak dapat dijadikan landasan berpijak runtuhnya teori lawan.

Strategi yang penting lainnya dalam mengajarkan evolusi pada tatanan perspektif yang benar adalah dengan menekankan pada karakter sains. Alles (2001) menyebutkan penguasaan karakter sains sangat berpengaruh dalam memahami bingkai konsep biologi, yakni pada integrasi antara pengetahuan biologi dengan sejarah kehidupan ataupun dengan masyarakat. Sains menuntut penggunaan bukti fisik dalam menginterpreptasi mengenai alam itu sendiri. Hal ini tidak lantas berarti bahwa kita harus mengamati setiap kejadian dalam alam untuk memahaminya secara saintifik. McMullin (1998) dalam Alles (2001) menyatakan bahwa dalam kaitan memahami sejarah biologi, dapat digunakan inferensi (kesimpulan) logis atau dikenal sebagai retroduction, dari bukti fisik yang ada saat ini mengenai kesimpulan sesuatu yang terjadi di masa lampau.

Pembelajaran mengenai karakter sains dan berpikir kritis akan menolong siswa dalam mengambil keputusan dalam mempercayai teori asal-usul makhluk hidup mana yang menurutnya benar. Kalaupun siswa memiliki kepercayaan untuk memahami sesuatu tanpa berdasarkan bukti faktual, maka konsekuensinya telah diketahui, yaitu apa yang dipercayainya tidak tergolong kategori ilmiah. Meskipun apa yang nantinya dipercayai bertentangan dengan apa yang dipercayai oleh siswa sebelum mempelajari evolusi yang diajarkan dengan teknik ini, siswa akan dapat menerimanya. Di luar itu, melalui pembelajaran seperti ini, maka siswa akan ditantang untuk berpikir logis dan mungkin memacu pengembangan kedua teori, baik evolusi atau ID, dan bukan justru mematahkan semangat mereka dalam menggali kebenaran evolusi atau ID seperti yang terjadi apabila seorang guru mengajarkan materi ini dan telah terlebih dahulu memihak pada salah satu teori.

\section{Penutup}

Teori ID dapat diajarkan di sekolah menengah sebagai teori pembanding evolusi, namun perlu dipertimbangkan penyajian teori ID secara tepat dan proporsional. Dalam proses pembelajaran, teori ID sebaiknya disajikan dengan memaparkan fakta-fakta saintifik terkait bukti-bukti ilmiah. Kaitan antara ID dan agama sebaiknya dihindari untuk mencegah terjadinya pemahaman yang bias terhadap pengambilan kesimpulan secara saintifik. Pola pengajaran yang sebaiknya ditempuh untuk mengatasi bias non saintifik adalah dengan menerapkan teknik debat. Penggunaan teknik ini juga dapat berdampak tidak langsung terhadap peningkatan keterampilan berpikir 
kritis dan pengembangan proses sains pada siswa.

\section{Daftar Rujukan}

Anonim. 2008. Menolak Evolusi Menghina Tuhan.

http://rosenqueencompany.w ordpress.com/2008/06/14/me nolak-teori-evolusi-adalahmenghina-tuhan/. Diakses tanggal 20 Mei 2009.

Alles, D.L. Using Evolution as The Framework for Teaching Biology. The American Biology Teacher. Volume 63. No. 1. Januari 2001.

Cherif, A., G. Adams dan J. Loehr. 2001. What on Earth Is Evolution: The Geological Perspective of Teaching Evolutionary Biology Effectively. The American Biology Teacher. Volume 63. No. 8. October 2001.

Djunaidi.H. 2005. Teori Evolusi dan Akibat-Akibat yang Ditimbulkannya. http://hendrikofirman.wordpr ess.com/2009/01/10/toerievolusi-darwin-islamepistimologis/. Diakses tanggal 20 Mei 2009.

Heady, J.E. Intelligent Design Creationism: A Threat to Society-Not Just Biology. The American Biology Teacher. Vol. 65. No.9 November/December 2001.

Herlina, I., Yani, R., Hanum, E.L., Purwaningsih, W., Peniasiani, D., dan Musarofah. 2009. Biologi 3 SMA dan MA Kelas XII. BSE. Pusat Perbukuan Depdiknas.
Subardi, Nuryani, dan Pramono S. 2009. Biologi 3 Untuk Kelas XII SMA dan MA. BSE. Pusat Perbukuan Depdiknas.

Kistinnah, I., dan Lestari, E.S. 2009. Biologi 3 Makhluk Hidup dan Lingkungannya Untuk SMA/MA Kelas XII. BSE. Pusat Perbukuan Depdiknas.

Jasin, M. 2008. Ilmu Alamiah Dasar. Edisi Revisi. Penerbit Rajawali Pers: Jakarta

Lutfi. 2003. Pembelajaran Perkembangan Hewan Berbasis Problem Solving yang Diintervensi dengan Peta Konsep dan Pengaruhnya terhadap Berpikir Kritis dan Hasil Belajar Mahasiswa Biologi FMIPA Universitas Negeri Padang. Disertasi tidak diterbitkan. Malang: Program Pascasarjana Universitas Negeri Malang

Mahladi. Selamat Datang Teori Perancangan Cerdas. Majalah Hidayatullah. Edisi 09/XVIII/Januari 2006.

Moore, K.D. 2005. Effective Instructional Strategies From Theory to Practice. SAGE Publication: Thousand Oaks. p: 325

National Centre for Science Education. 2012. Review: "Evolution - A Theory in Crisis" by Phillip T. Spieth . 1987. Zygon, vol. 22, no. 2 (June 1987) http://ncse.com/creationism/a nalysis/review-evolutiontheory-crisis. diakses tanggal 1September 2012. 
Proulx, G. 2004. Integrating

Scientific Method and

Critical Thinking in

Classroom Debates on

Environmental Issues. The

American Biology Teacher.

Volume 66. No.1. January.

Quammen, D. The Darwin

Bicentennial. National

Geographic. Edition

February 2009.

Parker, S. P. 1997. Dictionary of Bioscience. International Ed. McGraw Hill. New York.

Randak, S. The Children Crusade for Creationism. The American Biology Teacher. Vol. 63. No.4 April 2001.

Schafersman, S.D. 1991. An Introduction To Critical Thinking. http://www.proquestumi.com/pqdweb/critical_thi nking, diakses tanggal 29 November 2008

Sprachen, A. 2007. Evolusi Atheis. http://us 1.harunyahya.com/D etail/T/6HQIRVG4296/prod uctId/4487/EVOLUSI:_DOK TRIN_ATEIS_BERKEDOK SAINS. Diakses tanggal 20 Mei 2009

Stearns, S.C. dan R.F. Hoekstra. 2003. Evolution: an Introduction. Oxford University Press. England.

Tarihoran, A. 2012. Lampiran Peraturan Menteri Pendidikan Republik Indonesia Nomor 22 Tahun 2006 tentang Standar Isi Untuk Satuan Pendidikan Dasar dan Menengah. Mata Pelajaran Biologi SMA. http://afwansanur.blogspot.c om/2012/08/standarkompetensi-dan-kompetensidasar 8121.html. diakses tanggal 1 September 2012.

Trani, R. 2004. I Won't Teach Evolution; It's Against my Religion. The American Biology Teacher. Volume 66. No. 6 Agustus 2004.

Vuletic, M.I. 1997. Review of Michael Denton's Evolution: A Theory in Crisis. http://www.talkorigins.org/fa qs/denton.html. diakses tanggal 1 September 2012.

Wikipedia ${ }^{1}$. 2008. Evolusi. http://id.wikipedia.org/wiki/ Evolusi. Diakses tanggal 20 Mei 2009.

Wikipedia $^{2}$. 2008. CreationEvolution Controversy. http://en.wikipedia.org/wiki/ Creationevolution_controversy. Diakses tanggal $20 \mathrm{Mei}$ 2009.

Wikipedia. 2009. Intelligent Design. http://en.wikipedia.org/wiki/I ntelligent_design Diakses tanggal 13 Juni 2009.

Yahya, H. 2005. Bagaimana Sains Modern Membantah Darwinisme. Buku Satu. Alih bahasa: Effendi. Penerbit Dzikra. Bandung. 